\title{
Results of surgical treatment in metacarpal shaft fractures using low profile mini plates
}

\author{
Serkan Aykut, M.D., ${ }^{1}$ Kahraman Öztürk, M.D., ${ }^{1}$ Çağrı Özcan, M.D., ${ }^{2}$ \\ Murat Demiroğlu, M.D., ${ }^{1}$ Ahmet Utku Gürün, M.D., ${ }^{1}$ Erdem Özden, M.D. ${ }^{1}$
}

${ }^{1}$ Department of Hand and Upper Extremity Surgery, Metin Sabancı Baltalimani Bone Diseases Training and Research Hospital, Istanbul 2Department of Orthopedics and Traumatology, Metin Sabancı Baltalimani Bone Diseases Training and Research Hospital, Istanbul

\begin{abstract}
BACKGROUND: Metacarpal fractures are among the most common fractures of the hand. They may lead to loss of function if treated improperly. These injuries can be treated conservatively. However, if significant shortening, rotational deformity and angulation occur, surgical treatment is required. In this article, results of metacarpal fractures treated with open reduction and internal fixation with mini plates were presented.
\end{abstract}

METHODS: We retrospectively reviewed the clinical and radiologic records of twenty-nine consecutive patients with 37 metacarpal fractures treated by open reduction and internal fixation with low profile mini plate fixation between 2006 and 2013 . Surgical treatment with dorsal approach was planned for cases with unacceptable shortening, rotational deformity, and angulation. Early active motion was begun in all cases postoperatively. Patients were permitted to use their hands in daily activities four weeks after surgery. For objective assessment, total range of joint motion was measured. Rotational deformity of the fingers was assessed. Grip strength and quick DASH scores were compared with the uninjured side. Metacarpal shortening was evaluated radiologically, and angulation was measured.

RESULTS: Mean age was 35.I years (19-6I years) and mean follow-up period was 32 months (6-39 months). While mean operation time was 8.48 days (2-23 days), mean shortening was $7.58(2-30) \mathrm{mm}$. In cases with radiologically documented union, mean angulation in the posteroanterior plane was $8.13(0-42)$ degrees preoperatively and $3.55(0-28)$ degrees postoperatively. In lateral X-rays, mean angulation was 8.22 (0-39) degrees preoperatively and 3.66 (0-28) degrees postoperatively. Mean quick DASH score was 3.6 (0-I I.4). Mean grip strength measurements by Jamar hand dynamometer were $41.05( \pm 8.3) \mathrm{kg}$ for fractured hands, 44.7 ( \pm 9$) \mathrm{kg}$ for normal hands. No significant relationship was found between normal hand and fracture hand by Mann-Whitney $U$ test.

CONCLUSION: As in general fracture treatment principles, goals in metacarpal fracture treatment are obtaining an anatomical and stable reduction, fracture union and beginning early movement to avoid loss of function. Open reduction and low profile titanium plate application in metacarpal fractures is the choice of treatment in suitable cases as it meets the above mentioned treatment principles.

Key words: Low profile; metacarpal shaft fractures; miniplate; osteosynthesis.

\section{INTRODUCTION}

Metacarpal fractures constitute $30 \%$ of hand fractures. ${ }^{[1]}$ Fractures of the metacarpal shaft occur as a result of axial loading, torsion, or direct falls and are classified as transverse, oblique, or comminuted. ${ }^{[1-9]}$ The fractures of all metacarpals from the

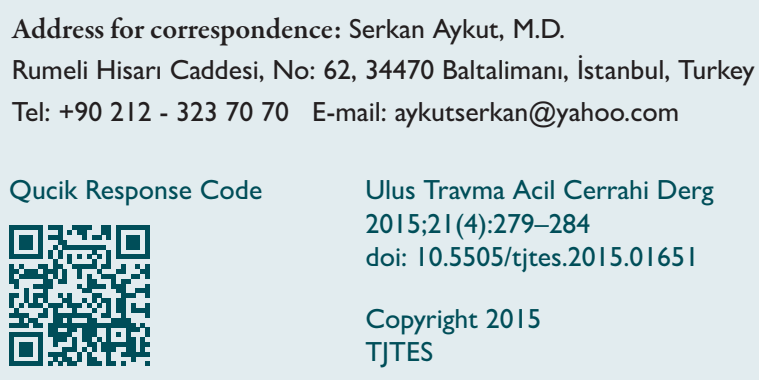

second to the fifth are characterized by edema and deformity, and inappropriate treatment may result in functional loss in the hand and disability. ${ }^{[4,9-11]}$ The goals of treatment are restoration of length, correction of rotational deformity, if present, establishing adequate stability, proper soft tissue management, and early initiation of movement. The treatment of metacarpal shaft fractures can be further sub-classified as transverse, oblique, spiral, or comminuted based on the fracture geometry. Stepping on hand or ball shock, as examples of direct trauma, mostly causes transverse and comminuted fracture, whereas sprain injuries like falling on the outstretched arm causes spiral and oblique fracture. ${ }^{[4,12,13,14]}$ Most metacarpal fractures are treated conservatively. ${ }^{[1-3,9,11,15-21]}$ If closed methods fail to achieve or maintain reduction when there is angulation, rotation or shortness because of the location (intra articular vs. extra articular), surgery could be used. Oblique and spiral fractures are prone to malrotation so operative 
fixation could be necessary, whereas comminuted fractures with or without segmental bone loss demand restoring and maintaining metacarpal length. ${ }^{[2-4,6,11,13,15,20,22,23]}$ Surgical methods include percutaneous or open Kirschner wire fixation, intramedullary fixation, open or percutaneous interfragmentary screw fixation, and external fixation. ${ }^{[1,2,10,16,24,25]}$

Kirschner wires are the most commonly used fixation materials after closed or open reduction. ${ }^{[2,15]}$ However, late initiation of movement resulting in a stiff hand, pin tract infection, and pin migration are the disadvantages of this method. ${ }^{[2,3,26]}$ Plate and screws provide a stable fixation in metacarpal fractures, and thus, allow for early motion and contribute significantly to the outcome. K-wire is a stable method in cases where soft tissue is intact. Soft tissues support the power of fracture fixation. Plate fixation is used in comminuted metacarpal fractures. ${ }^{[1,2,11,16,17,20,26-28]} A$ stable fixation allows for passive and active movements in intrinsic muscles affected by the trauma, significantly improving hand functions. Preservation of the anatomic reduction prevents rotational deformity. ${ }^{[1,24,27]}$ In patients treated with plate and screw osteosynthesis, an adequate stability was achieved and early motion was initiated. All patients returned to their preinjury occupations, and none had angulation or rotational deformities. ${ }^{[17,26]}$

The aim of this study was to assess the clinical and radiologic outcomes of patients with metacarpal fractures, who underwent open anatomic reduction and fixation with low profile titanium plates in our department.

We planned to show that by using plate osteosynthesis in metacarpal body fractures, good functional results could be obtained with early initiation of motion, good results could be achieved radiologically, and rotational deformity could be corrected, shortness could be totally prevented, and thereby, extensor lag could be avoided; however, complications such as tendon irritation could develop.

\section{MATERIALS AND METHODS}

A retrospective analysis of the clinical and radiologic data of 37 metacarpal fractures in twenty-nine patients operated in our department with low profile $2.0 \mathrm{~mm}$ non-locking titanium miniplates and screws between 2006-2013 was carried out. Open, thumb metacarpal, intra articular fracture, metacarpal neck fracture, and patients with other fractures in the same upper extremity were excluded.

2-5 $\mathrm{mm}$ shortness, rotational deformity, angulation greater than $20^{\circ}$ for index and long finger; greater than $30^{\circ}$ for ring finger and greater than $40^{\circ}$ for little finger were indications for surgery ${ }^{[23,29]}$ that was unacceptable after closed reduction and casting in clam digger position. All patients were operated in supine position and under infraclavicular block. After the tourniquet was inflated, the forearm was placed in prona- tion, a dorsal longitudinal incision was made, and the fracture was exposed with adequate soft tissue dissection. Excessive soft tissue dissection and periosteal sleeving was avoided. A low profile $2.0 \mathrm{~mm}$ titanium miniplate was applied with fixation of at least four cortices, two on each side of the fracture. In oblique or spiral type of fractures, those fractures suitable for interfragmentary screw fixation were initially fixed with interfragmentary screws, and then, by plate fixation (Fig. Iaf). Metacarpal alignment and angulation were confirmed with fluoroscopy. The plate and screws were covered with periosteum and soft tissues.

After the operation, a short arm splint was applied in functional position until the edema and pain subsided, and the extremity was elevated for the first 24-48 hours. Depending on the general condition of the patient, type of fracture and fixation method, active finger and metacarpophalangeal joint motion was initiated on the second postoperative day. Based on these same factors, the patients were allowed to use their hands in daily activities after the fourth postoperative week and in activities requiring force after the sixth week.

During the final follow up, total range of motion was assessed, grip power was measured and compared with the normal extremity. Quick DASH scoring was performed in all patients. Union, angulation, and shortness were assessed on PA, lateral, and 30 to $45^{\circ}$ pronation and/or supination oblique $X$ rays that were taken on postoperative first, third and sixth months and final follow up. The complications were noted.

\section{RESULTS}

There were twenty-five male and four female patients, and the fracture was located in the left hand in eighteen patients and in the right in eleven. Six of the patients had multiple fractures. The fractures were caused by falling on the hand in eighteen patients, fisting in five, crush injury in four, sports injury in one, and traffic accident in one. Mean age was 35.I (I9-6I) years and mean follow up was 32 (6-93) months. Mean interval between the injury and operation was 8.48 (2-23). The fracture was in the $2^{\text {nd }}$ metacarpal in 12 fractures, $3^{\text {rd }}$ in $9,4^{\text {th }}$ in 9 , and $5^{\text {th }}$ in 7 . The type of fracture was oblique in twenty-eight, transverse in six, and comminuted in three patients (Table I). $2.0 \mathrm{~mm}$ adaptation plate was used for six transverse, $T$ shaped plate for twenty-eight oblique, and three for comminuted fractures with bridge technique

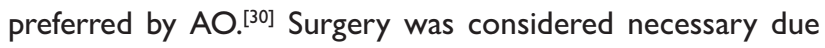
to angulation in eighteen patients, and shortness in eleven.

Total range of motion was 27I.I (245-275) degrees. Mean grip strength, measured with Jamar's hand dynamometer, was $41.05( \pm 8.3)$ in the fractured side, and $44.7( \pm 9) \mathrm{kg}$ on the normal side. Strength of firm hand and fracture was evaluated by Mann-Whitney $U$ test with IBM SPSS 22.0 program, and a significance level of $\mathrm{p}<0.05$ was accepted. No significant rela- 

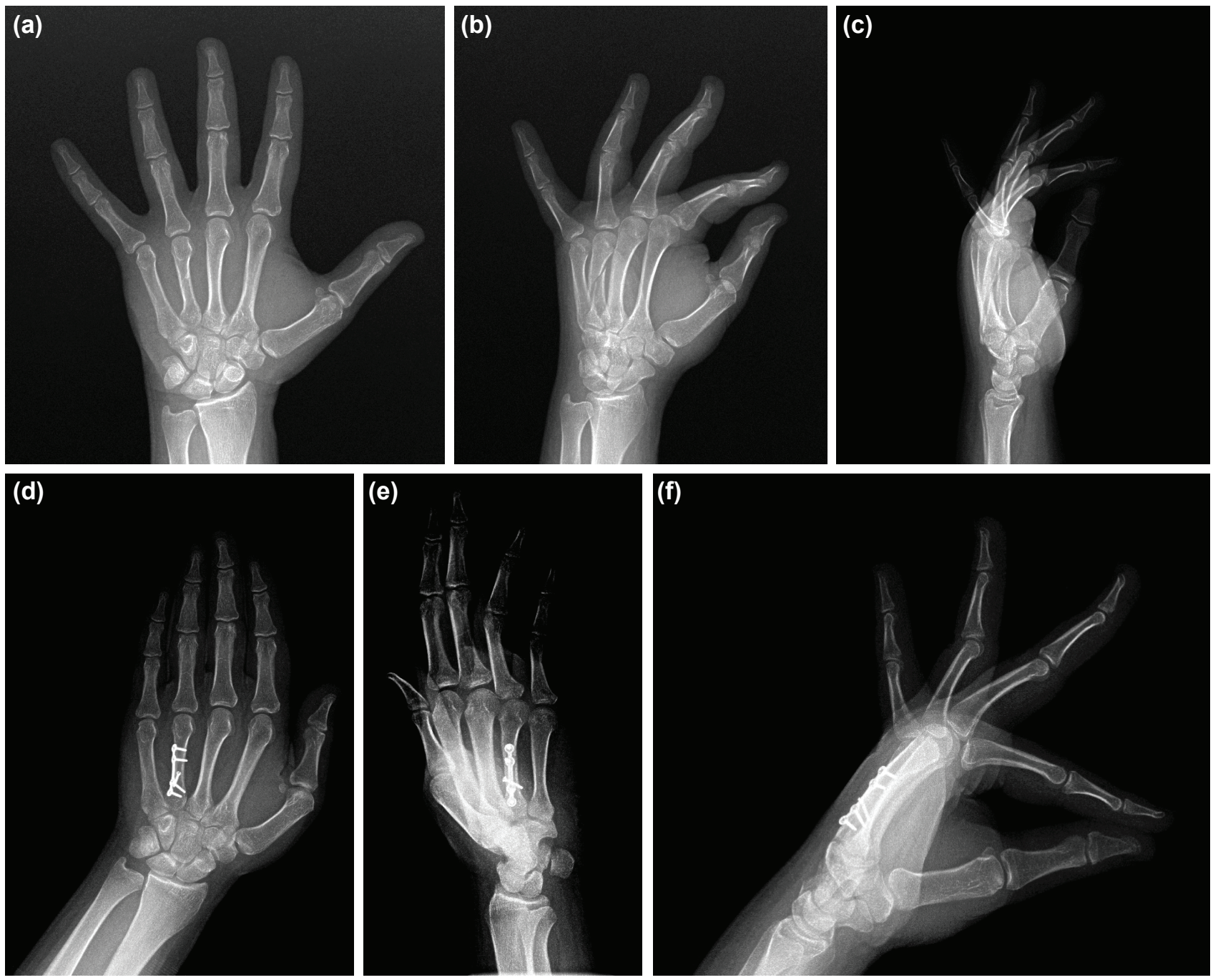

Figure 1. Nineteen year old patient's X-ray of left hand and fingers (a) AP / (b) oblique / (c) lateral shows oblique fracture of $4^{\text {th }}$ metacarpal with rotational deformity and shortening at the fracture site. Postoperative $6^{\text {th }}$ month (d) AP / (e) oblique / (f) lateral $x$-rays show perfect reduction was achieved with use of low-profile mini-plate and screws.

tionship was found between the firm hand and fracture hand by Mann-Whitney $U$ test $(p=0.203)$.

Mean quick DASH score was 3.6 (0-II.4). Radiologic union was achieved in all patients. Mean angulations before and after the operation were $8.13(0-42)$ and $3.55(0-28)$ degrees in the anteroposterior plane; and $8.22(0-39)$ and $3.66(0-28)$ degrees in the sagittal plane, respectively. Only one patient developed a rotation problem which was later corrected.

Mean shortness was $7.58(2-30) \mathrm{mm}$. Four patients (13.7\%) had restricted movement in the follow up on the sixth week, which resolved with the lengthening of the rehabilitation program. Four of the patients had difficulty in movement and also signs of tenosynovitis, and hence, the hardware was removed with a second operation in these patients. One patient

Table I. Type of the fractures

\begin{tabular}{lccccc}
\hline & 2. Metacarpal & 3. Metacarpal & 4. Metacarpal & 5. Metacarpal & Total \\
\hline Oblique & 8 & 6 & 8 & 6 & 28 \\
Transverse & 3 & 1 & 1 & 1 & 6 \\
Comminuted & 1 & 2 & - & - & 3 \\
& 12 & 9 & 9 & 7 & 37 \\
\hline
\end{tabular}


(3.44\%) had $3 \mathrm{~mm}$ shortness, $30^{\circ}$ angulation, and rotational deformity that interfered with function of the fifth finger. $A$ revision operation was performed. All patients returned back to their preoperative occupations.

\section{DISCUSSION}

In this study, metacarpal body fractures were operated on using low profile titanium plates and based on $\mathrm{AO}$ principles. ${ }^{[30]}$ Adequate stability was achieved in all patients, allowing early movement. All patients could return to their preoperative occupations. Except for the patient who underwent revision surgery, none of the patients had displacement, angulation, and rotational deformity. Due to irritation of plaque material and tendon adhesion after dorsal approach, material extraction could be done after surgical treatment of metacarpal fracture. In a study of Mumtaz et al. including forty cases, rate of material extraction has been $20 \% .{ }^{[20]}$ In our study; only four of the patients $(\% / 3)$ required hardware removal due to plate irritation, which we believe to be a relatively low rate owing to the use of low profile plates and respect to soft tissues.

Respect to soft tissue or tissue damage that occur during fracture are milestones of healing and stabilization of the fracture. In a cadaveric study of Ouellette et al., metacarpal fractures plaqued by dorsal approach have been compared biomechanically with soft tissues completely peeled off and intact. Fixation strength has been found significantly different in soft tissue intact group. ${ }^{[28]}$ Kato et al., have shown that minimizing soft tissue damage in comminuted fractures during surgery causes no significant difference in rigidity of the fixated anatomically bone to bone with completely peeled of soft tissue, even to be non-reducted anatomically after internal fixation. ${ }^{[3]}$ In our study, minimally invasive surgical approach was used as recommended by AO. A dorsal approach was used in all patients, and excessive soft tissue or periosteal dissection was avoided. The plates were applied from the dorsal aspect of the metacarpals and to four cortices, with two on each side of the fracture. An additional interfragmentary compression screw was applied in especially long oblique fractures. ${ }^{[30]}$

Lack of agreement in surgical management of metacarpal fractures, retrospective nature of most studies, and handling of these fractures together with phalangeal fractures are the limitations of this topic. We believe that prospective multicenter studies that compare various surgical methods will provide evidence based data.

The metacarpal bones are the longest tubular bones in the hand and form a stable platform for the fingers and the crucial anatomic structures on the volar aspect. ${ }^{[1]}$ Fibrocartilagenous volar plates and deep intermetacarpal ligaments form a strong construct between the metacarpals and prevent shortness in metacarpal fractures. Most transverse fractures angulate dorsally due to unbalanced traction of the interosseous muscles and the effects of the extrinsic extensor tendons on the distal fracture segment. This dorsal angulation may be tolerated up to $10^{\circ}$ in the second metacarpal and $20^{\circ}$ in the third, which are relatively immobile, and up to $30^{\circ}$ in the fourth metacarpal and 40 degrees in the fifth, which have greater mobility at the carpometacarpal joints. Oblique and spiral fractures of the metacarpals are less stable fractures and have a tendency for shortness and rotation. Therefore, angulations in metacarpal fractures must be measured and should be evaluated according to which metacarpal bone is fractured. Every 2 $\mathrm{mm}$ of shortness results in a $7^{\circ}$ extensor lag. ${ }^{[32]}$ Similarly, the metacarpals are very intolerant to any rotational deformity. Only $5^{\circ}$ of malrotation results in $1.5 \mathrm{~cm}$ overlap when the fingers are in flexion. Therefore, when deciding for surgery, the type of the fracture, angulation, shortness, and rotation should be assessed, and a decision should be made separately for each metacarpal.

Since most metacarpal fractures are stable, they can be managed successfully after reduction using conservative methods such as splinting. ${ }^{[1-3,15-18,20,21,24]}$ After closed reduction, immobilization should be made in the intrinsic-plus or "clam-digger" position (wrist in 30-40 degrees extension, metacarpophalangeal joints in 80-90 degrees of flexion, and the interphalangeal joints in full extension) with a thermoplastic splint, plaster or fiberglass short-arm cast. If metacarpal rotation, length, and angulation cannot be obtained or maintained, operative stabilization is necessary. These latter types of fractures constitute a relatively smaller fraction of metacarpal fractures.

There are various alternatives in the surgical treatment of unstable or displaced metacarpal fractures, which are $\mathrm{K}$ wire fixation, cerclage wires or intramedullary wiring with or without $\mathrm{K}$ wires, locking or nonlocking miniplates and screws, and external fixation. ${ }^{[1-4,10,24,25]}$ In vitro biomechanical comparative studies have shown that dorsal plating is the most stable fixation method. ${ }^{[2,10,33,34]} \mathrm{K}$ wire fixation may be made percutaneously in a cross, transverse, or intramedullary manner. $\mathrm{K}$ wires are easily available in the operating rooms, and are easily applied. They can be introduced percutaneously, which may protect from the problems related to open surgery. ${ }^{[1]}$ Percutaneous insertion; however, may result in tendon adhesions or even ruptures. ${ }^{[3]} \mathrm{K}$ wires cannot provide adequate biomechanical stability and are prone to complications including restricted motion and stiffness. ${ }^{[3]}$ Wire ends are left outside the skin, commonly resulting in problems such as implant loosening and infection. Kaiser et al. have published a series of children treated with a single elastic stable intramedullary wire, and only one patient needed wire removal for skin irritation, and none of the remaining patients had an infection or secondary surgery. ${ }^{[18]}$ Ozer et al. have compared intramedullary nailing with plate and screw fixation in a series of thirty-eight patients and found that although the two groups were similar with respect to the clinical results, the operative times were shorter in the intramedullary nail group. $^{[35]}$ On the other hand, reduction loss, penetration of 
material into the metacarpophalangeal joint, and secondary surgery for removal of the material were higher in the intramedullary nail group. ${ }^{[27]}$

Dorsal mini plating with steel or titanium plates is a method with increasing popularity. Lateral plating of metacarpal fractures is not appropriate because it is biomechanically very weak compared to dorsal plating. ${ }^{[34]}$ When compared with the wiring method, it provides a stable fixation when at least 2 or 3 bicortical screws are inserted to each side of the fracture. ${ }^{[1,10,34]}$ Early initiation of active and passive motion can prevent intrinsic tightness. On the other hand, complications such as material failure and irritation, infection, and nonunion have been reported to be as high as 35\%.[22,36] These series handled phalangeal fractures together with metacarpal fractures, and more recent studies involving only metacarpal fractures have reported lower complication rates. ${ }^{[1,21,22,26,36]}$ We believe that the reason for the relatively lower complication rates in our series was the inclusion of only metacarpal fractures, performance of minimal soft tissue and periosteal stripping, and use of low profile plates.

The use of low profile titanium plates in metacarpal fractures provides a stable fixation and allows early movement, which are significant advantages over other methods.

\section{Conflict of interest: None declared.}

\section{REFERENCES}

1. Diaz-Garcia R, Waljee JF. Current management of metacarpal fractures. Hand Clin 2013;29:507-18. CrossRef

2. Adams JE, Miller T, Rizzo M. The biomechanics of fixation techniques for hand fractures. Hand Clin 2013;29:493-500. CrossRef

3. Blazar PE, Leven D. Intramedullary nail fixation for metacarpal fractures. Hand Clin 2010;26:321-5. CrossRef

4. Dean BJF, Little C. Fractures of the metacarpals and phalanges. Orthopedics and Trauma 2011;25:43-56. CrossRef

5. Henry MH. Fractures of the proximal phalanx and metacarpals in the hand: preferred methods of stabilization. J Am Acad Orthop Surg 2008;16:586-95.

6. McNemar TB, Howell JW, Chang E. Management of metacarpal fractures. J Hand Ther 2003;16:143-51. CrossRef

7. Nakashian MN, Pointer L, Owens BD, Wolf JM. Incidence of metacarpal fractures in the US population. Hand (N Y) 2012;7:426-30. CrossRef

8. Soong $\mathrm{M}$, Got $\mathrm{C}$, Katarincic J. Ring and little finger metacarpal fractures: mechanisms, locations, and radiographic parameters. J Hand Surg Am 2010;35:1256-9. CrossRef

9. Sennet BJ. Operative treatment of metacarpal fractures of the hand (excluding thumb metacarpal fractures). Operative Techniques in Orthopaedics 1997;7:127-33. CrossRef

10. Black D, Mann RJ, Constine R, Daniels AU. Comparison of internal fixation techniques in metacarpal fractures. J Hand Surg Am 1985;10:46672. CrossRef

11. Fusetti C, Garavaglia G, Papaloïzos M. Re: Souer JS, Mudgal CS. Plate fixation in closed ipsilateral multiple metacarpal fractures. J Hand Surg Eur 2008;33:740-4. J Hand Surg Eur Vol 2009;34:560-2. CrossRef
12. Ochman S, Doht S, Paletta J, Langer M, Raschke MJ, Meffert RH. Comparison between locking and non-locking plates for fixation of metacarpal fractures in an animal model. J Hand Surg Am 2010;35:597-603. CrossRef

13. Rhee PC, Becker HA, Rizzo M. Update on the Treatment of Metacarpal Fractures. Curr Orthop Pract 2012;23:289-95. CrossRef

14. Gereli A, Nalbantoğlu U, Türkmen M. Sporcularda görülen metakarp ve falanks kırıkları TOTBİD Dergisi 2012;11:220-7.

15. Al-Qattan MM. Outcome of conservative management of spiral/long oblique fractures of the metacarpal shaft of the fingers using a palmar wrist splint and immediate mobilisation of the fingers. J Hand Surg Eur Vol 2008;33:723-7. CrossRef

16. Baldwin PC, Wolf JM. Outcomes of hand fracture treatments. Hand Clin 2013;29:621-30. CrossRef

17. Ford DJ, el-Hadidi S, Lunn PG, Burke FD. Fractures of the metacarpals: treatment by A. O. screw and plate fixation. J Hand Surg Br 1987;12:347. CrossRef

18. Kaiser MM, Tafazzoli K, Theilen TM, Schulz AP, Paech A, Wessel LM. Intramedullary nailing for metacarpal 2-5 fractures. J Pediatr Orthop B 2009;18:296-301. CrossRef

19. Meals C, Meals R. Hand fractures: a review of current treatment strategies. J Hand Surg Am 2013;38:1021-31. CrossRef

20. Mumtaz MU, Farooq MA, Rasool AA, Kawoosa AA, Badoo AR, Dhar SA. Unstable metacarpal and phalangeal fractures: treatment by internal fixation using AO mini-fragment plates and screws. Ulus Travma Acil Cerrahi Derg 2010;16:334-8.

21. Nalbantoğlu U, Gereli A, Uçar BY, Kocaoğlu B, Doğan T. Treatment of metacarpal fractures with open reduction and low-profile plate and screw fixation. [Article in Turkish] Acta Orthop Traumatol Turc 2008;42:3039. CrossRef

22. Page SM, Stern PJ. Complications and range of motion following plate fixation of metacarpal and phalangeal fractures. J Hand Surg Am 1998;23:827-32. CrossRef

23. Green's Operative Hand surgery Fifth Edition 2005;1:283-5.

24. Ouellette EA, Freeland AE. Use of the minicondylar plate in metacarpal and phalangeal fractures. Clin Orthop Relat Res 1996;327:38-46. CrossRef

25. Margić K. External fixation of closed metacarpal and phalangeal fractures of digits. A prospective study of one hundred consecutive patients. J Hand Surg Br 2006;31:30-40. CrossRef

26. Kumar S, Mohanta S. Treatment of unstable metacarpal fractures by miniplate and screws. J Clin Orthop Trauma 2010:66-70.

27. Ozer K, Gillani S, Williams A, Peterson SL, Morgan S. Comparison of intramedullary nailing versus plate-screw fixation of extra-articular metacarpal fractures. J Hand Surg Am 2008;33:1724-31. CrossRef

28. Ouellette EA, Dennis JJ, Milne EL, Latta LL, Makowski AL. Role of soft tissues in metacarpal fracture fixation. Clin Orthop Relat Res 2003;412:169-75. CrossRef

29. C McCarty, JB Samora, HM Awan. Metacarpal shaft fractures: A review. OA Orthopaedics 2014;2:12.

30. Rüedi TP, Buckley RE, Moran CCAO. Principles of Fracture Management Second edition Part 2:685-7.

31. Kato S, Latta L, Burkhalter W. Mechanical evulation of external and internal fixation for metacarpal fracture. Trans Orthop Res Soc 1986;11:316.

32. Freeland AE, Geissler WB, Weiss AP. Surgical treatment of common displaced and unstable fractures of the hand. Instr Course Lect 2002;51:185-201.

33. Dumont C, Fuchs M, Burchhardt H, Appelt D, Bohr S, Stürmer KM. Clinical results of absorbable plates for displaced metacarpal fractures. J 
Hand Surg Am 2007;32:491-6. CrossRef

34. Vanik RK, Weber RC, Matloub HS, Sanger JR, Gingrass RP. The comparative strengths of internal fixation techniques. J Hand Surg Am 1984;9:216-21. CrossRef

35. Ozer K, Gillani S, Williams A, Peterson SL, Morgan S. Comparison of intramedullary nailing versus plate-screw fixation of extra-articular metacarpal fractures. J Hand Surg Am 2008;33:1724-31. CrossRef

36. Fusetti C, Meyer H, Borisch N, Stern R, Santa DD, Papalö̈zos M. Complications of plate fixation in metacarpal fractures. J Trauma 2002;52:535-9. CrossRef

\section{ORIJINAL ÇALIŞMA - ÖZET}

\section{Düşük profilli mini plak ile metakarp cisim kırıklarının cerrahi tedavi sonuçları Dr. Serkan Aykut, ${ }^{1}$ Dr. Kahraman Öztürk, ${ }^{1}$ Dr. Çağrı Özcan, ${ }^{2}$ Dr. Murat Demiroğlu, ${ }^{1}$ Dr. Ahmet Utku Gürün, ${ }^{1}$ Dr. Erdem Özden ${ }^{1}$}

${ }^{1}$ Metin Sabancı Kemik Hastalıkları Eğitim ve Araştırma Hastanesi, El Cerrahisi Kliniği, İstanbul

${ }^{2}$ Metin Sabancı Kemik Hastalıkları Eğitim ve Araştırma Hastanesi, Ortopedi ve Travmatoloji Kliniği, İstanbul

AMAÇ: Metakarpal kırıklar elde en sık rastlanan kırıklardandır. Uygun tedavi edilmedikleri takdirde fonksiyon kaybına neden olabilirler. Bu yaralanmaların çoğu konservatif olarak tedavi edilebilir. Ancak belirgin kısalma, rotasyonel deformite ve açlanma oluştuğunda cerrahi tedavi gereklidir. Bu yazıda metakarp kırıklarının açık redüksiyon ve mini plaklar ile tespitinin sonuçlarının sunulması amaçlandı.

GEREÇ VE YÖNTEM: Kliniğimizde 2006 ve 2013 yılları arasında düşük profilli mini plak osteosentezi yapılmış, klinik ve radyolojik takibi olan 29 hastanın 37 metakarp kırığı geriye dönük olarak incelendi. Kabul edilemeyen kısalık, rotasyonal deformite ve açılanma olan olgulara dorsal girişimle cerrahi girişim planlandı. Tüm hastalara ameliyat sonrası erken hareket başlandı. Hastalara ameliyattan dört hafta sonra günlük aktivitelerde ellerini kullanmalarına izin verildi. Objektif değerlendirmede toplam eklem hareket açıklı̆̆ı ölçüldü. Parmakların rotasyonel deformitesi değerlendirildi. Kavrama gücü ve QuickDASH skorları yaralanmamış taraf ile karşılaştıııldı. Metakarpal kısalık radyolojik olarak ölçüldü ve açılanma hesaplandı. BULGULAR: Ortalama yaş 35.I (19-6I) yıl, ortalama takip süresi 32 (6-39) aydı. Travma sonrası ameliyata kadar geçen süre ortalama 8.48 (2-23) gündü. Ortalama kısalık 7.58 (2-30) mm olarak ölçüldü. Radyolojik kaynamanın görüldüğü olgularda posteroanterior planda ortalama açıanma ameliyat öncesi 8.13 (0-42) derece, ameliyat sonrası 3.55 (0-28) derece olarak ölçüldü. Lateral grafilerde ortalama açılanma ameliyat öncesi 8.22 (0-39) derece, ameliyat sonrası 3.66 (0-28) derece olarak not edildi. Ortalama QuickDASH skoru 3.6 (0-1I.4) tü. Ortalama kavrama gücü kırık elde Jamar el dinamometrisi ile $41.05( \pm 8.3)$ kg, etkilenmemiş tarafta 44.7 ( \pm 9$)$ kg olarak ölçüldü. Sağlam el ile kırık el arasında kavrama gücü açısından Mann-Whitney $U$ testine göre istatistiksel olarak anlamlı bir fark elde edilmedi $(p<0.05)$. Ortalama eklem hareket açılı̆̆ı 27।.I (245-275) dereceydi. Dört olguda (\% 13.7) hareket kısıtlılı̆ı vardı, rehabilitasyon programı uzatılarak çözüldü. Yine dört hastada (\%।3.7) irritasyona bağı plak çıkarılmasına neden olan hareket kısıtlıı̆ı ve tenosinovit gelişmişti. Bir hastada (\%3.44) rotasyon ve kısalık ile kaynama gözlendi. Revizyon cerrahisi planlandı.

TARTIŞMA: Genel kırık prensiplerinde olduğu gibi metakarp kırıklarında da hedef kırığın uygun anatomik ve stabil redüksiyonunun sağlanarak tedavi edilmesi, kırı̆̆ın kaynamasının sağlanması ve fonksiyon kaybından kaçınabilmek için erken hareket başlanmasıdır. Yukarıda sayılan tedavi prensiplerini karşılayabildiğinden uygun olgularda açık redüksiyon ve düşük profilli mini titanyum plak uygulaması metakarp kırıklarının tedavisinde tedavi seçeneklerinden biridir.

Anahtar sözcükler: Düşük profilli; metakarp cisim kırıkları; mini plak; osteosentez.

Ulus Travma Acil Cerrahi Derg 2015;2I(4):279-284 doi: 10.5505/tjtes.2015.0165 I 